\title{
Factors Contributing to Low Teachers Competencies Score
}

\author{
Sabila Nahari ${ }^{1}$, Mohammad Adnan Latief ${ }^{1}$, Utari Praba Astuti ${ }^{1}$ \\ ${ }^{1}$ English Language Teaching-Universitas Negeri Malang
}

\begin{tabular}{l}
\hline INFO ARTIKEL \\
\hline Riwayat Artikel: \\
Diterima: 04-02-2020 \\
Disetujui: $14-08-2020$ \\
\hline
\end{tabular}

Kata kunci:

competencies score;

low competency teacher;

skor kompetensi;

guru berkompetensi rendah

\author{
Alamat Korespondensi: \\ Sabila Nahari \\ Pendidikan Bahasa Inggris \\ Universitas Negeri Malang \\ Jalan Semarang 5 Malang \\ E-mail: naharisabila@gmail.com
}

\begin{abstract}
ABSTRAK
Abstract: Competent teachers contribute to the students' achievement significantly. Therefore, the government established a teacher professional development program with various activities. The program aims to improve their teaching skills, professional knowledge, and teaching effectiveness. However, many teachers have low competency even after joining the teacher professional development program. The low teacher competency score can be seen from the result of the teacher competency test. This research uses a quantitative design to investigate factors that contribute to the teachers' competence. The results show factors that contribute to the low teachers' competence are not doing classroom action research and writing article, rarely attending seminars or workshop, never being a speaker at seminars, low frequency of maintaining their English skill, not understanding the rights, mechanism, implementation of teacher competency test, not understandingng the objective of teacher competency test as a condition job promotion, and the unreadiness of the teacher in taking the examination.

Abstrak: Guru yang kompeten berkontribusi terhadap prestasi siswa secara signifikan. Oleh karena itu, pemerintah membentuk program pengembangan profesional guru dengan berbagai kegiatan. Program ini bertujuan untuk meningkatkan keterampilan mengajar, pengetahuan profesional, dan efektivitas pengajaran mereka. Namun, banyak guru memiliki kompetensi rendah bahkan setelah mengikuti program pengembangan profesional guru. Skor kompetensi guru yang rendah dapat dilihat dari hasil tes kompetensi guru. Penelitian ini menggunakan desain kuantitatif untuk menyelidiki faktor-faktor yang berkontribusi terhadap kompetensi guru. Hasil penelitian menunjukkan faktor-faktor yang berkontribusi terhadap rendahnya kompetensi guru adalah tidak terbiasa melakukan penelitian tindakan kelas dan menulis artikel, jarang menghadiri seminar atau lokakarya, tidak pernah menjadi pembicara di seminar, rendahnya frekuensi guru dalam mempertahankan keterampilan bahasa Inggris mereka, tidak memahami hak, mekanisme, pelaksanaan tes kompetensi guru, tidak memahami tujuan tes kompetensi guru sebagai syarat promosi pekerjaan, dan ketidaksiapan guru dalam mengikuti ujian.
\end{abstract}

Education is expected to improve the quality of the human resources of a nation. In accordance with Law Number 20 of 2004 , the National Education System is a planned effort to realize an active learning process so that students can develop their potential to have religious-spiritual strength, self-control, personality, intelligence, noble character, and the other necessary skills. For this reason, the government and all those involved in education must pay attention and take careful planning to carry out education properly and adequately. Thus, national education goals can be realized in accordance with the mandate of the Act, especially for teachers who are the main actors in the implementation of learning in each educational institution in order to realize good quality education (Hanushek et al., 2019). Among all components in learning, the teacher is the main component that determines to learn success. According to Law No. 14 of 2005 concerning Teachers and Lecturers, teachers are professionals whose main tasks are educating, teaching, guiding, directing, training, assessing, and evaluating students. Therefore, they must have academic qualifications at the undergraduate or graduate level. In addition, they must also possess and master four teacher competencies: pedagogical, social, personal, and professional competencies, so that they can participate in implementing educational goals and play a role in developing students' potential.

Having good quality education and competent teachers is a must for every country to improve the quality of human resources (Arifin, 2014; Ngungi \& Thinguri, 2014). Most education stakeholders, such as students, parents, educators, and policymakers believe that student achievement at school is related to how competent the teacher is. (Mulyasa, 2013; Paige, 2002; Selvi, 2010; Taniredja \& Abduh, 2016; Weda, 2016) Therefore, every teacher in Indonesia needs to improve their knowledge and skills to complete their qualifications as professional educators. The activities that must be carried out to improve teacher 
professionalism are reading reputable journal articles, listening to the radio, watching the movie, joining communities for a teacher, attending seminars, workshops, and conferences in English (Elder, 1994; Osamwonyi, 2016; Richards, 2017). Since the teacher is a profession that requires special expertise, it is not enough to only have four skills. Teachers must have a balanced EQ and IQ in order to communicate and be able to convey subject matter to students properly and correctly (Barlożek, 2013; O’Shea, 2019).

The government has run various teacher training programs to ensure effective education system planning and development (Amalia \& Saraswati, 2018; A. F. Selvi, 2016). The government programs that have been carried out to support the quality of teachers through teacher professional development (Bautista \& Ortega-Ruiz, 2015; Boudersa, 2011; Kennedy, 2016; Rahman, 2011) involve self-development, scientific publications, and innovative teaching methods (Indrawati \& Octoria, 2016). The government has conducted various training for teachers, especially for English teachers. This training is also part of teacher professional development, which is carried out for approximately 5 to 10 days (Mrs. Alfi, personal communication. 2019, July 21). This program aims to improve teaching skills, mastery of teaching materials, and the commitment and motivation of teachers in conducting the learning process. The activities during the training period are making textbooks or learning modules, making learning media, designing student assessments, and improving reading, writing, listening, speaking, grammar, vocabulary, and pronunciation. In addition, the government also has a program to improve teacher welfare (Tanang $\&$ $\mathrm{Abu}, 2014)$, because many teachers are still poorly paid. However, it does not rule out the possibility of teachers having additional work besides being teachers which can disrupt their focus in carrying out their duties.

One of the government's ways to find out whether the teacher has qualified as a competent teacher is by conducting a teacher competency test namely UKG. According to government regulation number 57 of 2012, UKG is a test that is emphasized on pedagogical competence and professional competence in the cognitive domain. Pedagogical competence is the teacher's ability to understand students, design and implement learning, evaluate learning outcomes, and student development to actualize the various potentials they have. Pedagogical competency standards include (a) getting to know the characteristics and potential of students, (b) mastering learning theory and principles of active learning, (c) planning and developing curriculum, (d) implementing effective learning, and (e) assessing and evaluating learning. On the other hand, professional competence is the ability to master broad and deep learning material that enables the teacher to guide students to meet the competency standards set in the National Education Standards. For example, English teachers should master four language skills reading, writing, speaking, listening, and also language components grammar and pronunciation. Professional competencies in the field of study include (a) Mastery of material, structure, concepts and scientific mindset that supports the subjects to be taught, (b) Developing professionalism through reflective action, and (c) Consistency of mastery of teacher material between content and performance (text, context, and reality, facts, principles, concepts and procedures, and completeness about the mastery of philosophy, origins, and application of science) (PP No. 19 of 2005).

Even though the government has provided various teacher training programs as mentioned above, many English teachers are still classified low since level of competencies are not adequately achieved (Dahnial, Setiawan, et al., 2017; Adnan, 2018), lack skills in managing classroom efficiency and effectively (Mustafa, 2013), do not give impact on students' English ability (Haruchan, 2016). Moreover, based on preliminary research studies, data obtained from the education office in Pasuruan City, show that the average score of 176 teacher competency tests for secondary and vocational school teachers in Pasuruan Regency is 59, far below the minimum score. Usually, each location has different factors that contribute to the low competence of teachers, i.e., geographical, cultural, and economic factors. Therefore, this study tries to explore what factors contribute to the low competency scores of teachers in Pasuruan district, which refers to data from previous studies, from teachers who have below standard competency scores.

\section{METHOD}

In this study, quantitative research is used to find the answer to what contributes to the low-grade of teacher competency. The researcher uses the close-ended questionnaire in the form of yes or no questions. The questions of the questionnaire in this study are adapted from (Wulyani, 2017) and (Suyidno \& Yamin, 2015) study. The questionnaires are divided into three parts. The first part is about individual information, which covers three questions about the teachers' name, the teacher's gender, the teacher's teaching period, and the teacher's latest education. The second part is about their professional development, which covers eight questions about the teachers' participation in professional development programs. Then, the teachers are asked to describe the activities of professional development programs. Then, they are asked to mention other teachers who are not participating in the professional development program. The next question is about their affiliation with English teacher organizations, the teachers' habit in writing paper, the teachers' frequency in attending and becoming speakers in seminars or workshops. Last, the teachers were also asked to tell how they maintain or improve their English proficiency. After that, the last part of the questionnaire is about teacher competency tests which cover several aspects such as teachers understanding about the rights, mechanisms, functions, and objectives of implementing UKG; teachers' understanding about the purpose of teacher competency test as a requirement for job promotion; knowing the level of teacher readiness to take UKG and what factors contribute to their unpreparedness in taking UKG. 
The factors are divided into internal and external factors. The internal factors include the statement of available time during the test, UKG socialization, difficulty in operating the computer and the unsuitable question of the test. While the external factors include the lack of mastery, the lack of preparation, having problems with computers. The research participants are English teachers at four Senior High Schools and 2 Vocational High Schools in Pasuruan Regency, SMAN 1 Kejayan, SMAN 1 Gondangwetan, SMAN 1 Purwosari, SMAN 1 Bangil, SMKN 1 Bangil, and SMKN 1 Purwosari. The main criteria of the research subjects in this study are the English teachers who have taken the UKG test. The score data is obtained from Dinas Pendidikan Pasuruan. After that, the questionnaires were distributed to the English teachers who meet the criteria mentioned above. The sample was decided based on the education unit level of senior and vocational high school in Pasuruan regency. The subjects were 33 English teachers, 14 teachers with scores above standard (higher than 70) and 19 teachers with scores below standard (lower than 70).

\section{FINDINGS}

There are 33 teachers with 15-20 years of teaching experience, 8 out of 33 teachers (24\%) have master's degrees (S2), and the rest have bachelor's degrees (S1). All of the teachers stated that they must join the professional development programs because it is a mandatory task from the government. The activities in those programs are making lesson plans, media, and assessments. In addition, there were activities to improve their English proficiency skills, such as reading, writing, listening, speaking, and grammar. The teacher must wait until they get a recommendation from the government before they can participate in the programs.

Next, 14 teachers with scores above 70 and 15 teachers with competency test scores below the graduation standard joining the teacher forum. They benefit a lot from joining a teacher forum such as exchanging teaching, sharing information in solving problems in class, etc. Some teachers do not join the teacher forum because they can independently seek information about education from various other sources. However, some of those who join the forum still have grades below standard. 12 teachers out of $14(85 \%)$ with criteria above 70 do a lot of classroom action research or writing articles to solve problems in the classroom in addition to getting credit points for increasing teacher levels. In addition, only 10 out of 19 teachers (53\%) with competency score criteria below 70 do a lot of writing articles or conducting classroom action research.

Furthermore, 10 out of 14 teachers $(71 \%)$ with scores above 70 have participated in the workshops or seminars to enhance their knowledge and to keep updating the information about education. Only 12 out of 19 teachers (63\%) with a score below 70 attend the seminars. The other 11 teachers rarely attend the seminar because they have to spend most of their time to do the task. 8 out of 33 teachers $(24 \%)$ have experienced as the speakers at the seminar, 6 of them have scores above the standard and 2 of them have scores below the standard. They stated that being a speaker at the seminars can improve their communication skills in conveying information to anyone, especially to the students during the teaching and learning process in class. From 14 teachers who have scores above the standard, 10 of them often improve their English language skills, 2 of them sometimes, and two others never. The teachers with scores below 70, 10 of them often improved their English skills, six only occasionally and three teachers never. Those teachers choose not to improve their English proficiency because they do not have much time left as they still have many assignments to do. They also stated that teaching in class is part of the way they improve their English skills.

From 8 out of $14(57 \%)$ teachers with score above the standard choose to read English books, 12 out of 14 (86\%) teachers choose to watch English movies and listen to English music, and 7 out of 14 (50\%) teachers choose to write blogs in English to improve their English skills. While 8 out of $19(42 \%)$ teachers with scores below the standard choose to read English books, 12 out of $19(63 \%)$ teachers choose to watch an English movie, 15 out of $19(78 \%)$ teachers choose to listen to music and 5 out of $19(26 \%)$ choose to write blogs in English. 13 out of $19(68 \%)$ teachers whose scores are below the standard still do not see the importance of knowing the mechanisms, functions and objectives of the teacher competency test. Whereas 12 out of $14(85 \%)$ teachers who have scores above the standard understand the mechanisms, functions, and objectives of teacher competency tests. 12 out of $14(85 \%)$ teachers with scores above 70 know the purpose of the teacher competency test as a promotion. While only 7 out of $19(36 \%)$ teachers who score below 70 know the purpose of the teacher competency test as a promotion. Some teachers do not understand teacher competency tests due to a lack of socialization.

The level of the readiness of the teacher in taking the exam also has a considerable contribution to the results, 12 out of $14(85 \%)$ teachers who have scores above 70 ready to take the exam. While 10 out of 19 (53\%) teachers who have scores below 70 less prepared to take the exam. Then, the factors that contribute to the unpreparedness of the participants' conduct the UKG are divided into internal factors and external factors. The external factors, 15 out of $33(45 \%)$ teachers are lack of time to take the test. 15 out of $33(45 \%)$ teachers are lack of socialization about UKG test, 20 out of $33(61 \%)$ teachers get some problems with the computers, and 7 out of $33(21 \%)$ teachers expressed the questions are too difficult. Besides, some teachers convey that there is no specific day to conduct the teachers' competency tests. The exam is conducted when the teachers are still required to teach in their schools so that they lose their focus on doing the tests. Moreover, in the internal factor, 16 out of 33 (48\%) teachers find it difficult to use computers. 17 out of $33(51 \%)$ teachers do not master the materials to be tested, and 15 out of 33 $(45 \%)$ teachers did not prepare exams well. 


\section{DISCUSSION}

In this study, the researcher tries to cover what factors contribute to the low teacher competences score. Low teacher competency does not necessarily mean that they are incompetent teachers, it is contributed by many factors (Nhu et al., 2016): not doing classroom action research and writing article, rarely attending seminars or workshop, never being a speaker at seminars, low frequency of maintaining their English skill, not understand the rights, mechanism, implementation of teacher competency test, not understand the objective of teacher competency test as a condition job promotion, and the unreadiness of the teacher in taking the examination. Whereas participating in the teacher professional development and being a member of a teacher forum is not part of factor that contribute to the low teacher competences score, 14 out of 33 (42\%) teachers who had scores above the standard and 18 teachers who scored below the standard, had participate in the teacher professional development program. Although all the teachers join teacher professional development, they still have grades below the standard (Novozhenina \& Pinzón, 2018). Likewise, in spite of being a member of a teacher forum, many teachers still score below the standard (Ammentorp \& Madden, 2018). It is up to each teacher how to make the best use of existing facilities provided by the government which also has made various efforts to improve their competence by holding professional development and facilitating them to become members of the teacher forum.

Conducting classroom action research or writing articles is influential on the ability of teachers. By doing classroom action research or writing articles, the teacher will get broad insights about education so that they can solve problems in the classroom (Hine, 2013; Johnson, 2012; Kunlasomboon, Wongwanich, et al., 2015). It is proved from the results of the questionnaire that teachers who do a lot of classroom action research have better grades than those who do not do a lot of classroom action research and writing articles. Attending seminars or workshops have a contribution to the level of teacher competency (Elder, 1994; Osamwonyi, 2016; Richards, 2017), because by attending seminars or workshops the teacher will learn a lot from experts. Besides, the teacher can also sharpen their knowledge. As indicated on the results of the questionnaire, the more often the teachers attend seminars or workshops, the higher the score of the competencies they obtain. However, not many teachers attend the seminar. Furthermore, having no experience of being a speaker at a seminar is also one factor that contributes to the low competence of the teachers. Having experience of becoming a speaker at a seminar, increases communication skills, and enhances their knowledge because when they become speakers, they must read many sources.

Understanding UKG's rights, mechanisms, functions, objectives, and implementation as a requirement for job promotion is important. The higher the teacher's understanding of rights, mechanisms, functions, and goals, the higher the achievement they get. It is revealed from the questionnaire, that teachers who understand the objective of the teacher competency test, will learn more seriously and understand better how important to have maximum competence is. Teachers will automatically improve their ability to become professional since they have the responsibility to educate themselves to improve the quality of education (Marinković et al., 2012; Panggabean \& Himawan, 2016). The readiness of teachers in facing teacher competency tests also becomes one of the factors of the high and low scores of teacher competencies. Regarding the level of readiness of the teachers in taking the competency test, only around $42 \%$ of the English teachers say that they were ready to take the exam. External and internal factors contribute to the teachers' competency development. The external factors are the lack of available time in conducting the test, the lack of socialization about teacher competency tests, problems with the computer and the questions of the test which are too difficult. While Internal factors include the teachers' inability to use computers, lack of mastery of the material being tested and not preparing the exam well.

\section{CONCLUSION}

From the results of this study, it can be concluded that the low teachers competencies test score is contributed by various factors: not doing classroom action research and writing article, rarely attending seminars or workshop, never being a speaker at seminars, low frequency of maintaining their English skill, not understanding the rights, mechanism, implementation of teacher competency test, not understanding the objective of teacher competency test as a requirement for job promotion, and the unreadiness of the teacher in taking the examination. The unreadiness factors are divided into external and internal factors. External factors include insufficient time available to do the test, the lack of socialization about teacher competency tests, the problem with the computer, and the questions of the test which are difficult. While internal factors are teacher difficulties in operating the computers, not mastering the material well, and not preparing the exam well.

This study offers several suggestions for teachers and the government, as an education policymaker, and further researchers. The teacher should improve the four teacher competencies: pedagogic, personal, social, and professional competence, both theoretically and practically. It is because mastering all the teacher competencies is very important to become a professional teacher. Besides, teachers must also self-evaluate themselves, be aware of the weaknesses to know what skills need to be improved. In order to maximize the capabilities that teachers have, they should attend various teacher training activities, teaching workshops, and seminars provided by the government. However, if the government does not provide onservice training regularly, the teachers can improve themselves by reading, writing articles and doing classroom action research to help them to develop new knowledge related to their classroom, and improve their teaching performance to face problems in class. 
The next suggestion is addressed to the government as an educational policymaker. Besides running various teaching training and seminars to improve teacher quality, teacher certification programs, and continuous professional development, the government should also evaluate all of the programs that have been implemented to determine the extent of the success of the program. Then, the outcome of the evaluation can be used by the government in making decisions about whether the program is appropriate to be continued or to identify deficiencies that need to be revised or must be stopped. Moreover, in carrying out the test of teacher competency, the government should provide clear instructions on the implementation of teacher competency by giving guidance, especially to the teachers who will take a computer-based competency test by holding a simulation test.

\section{REFERENCES}

Adnan, Z. (2018). Upgrading EFL Teachers' Quality through An Online Mentoring System, An Innovative In-Service Training Model: The Case of Indonesia. Jurnal Humaniora, 30(2), 158-166. doi.org/102216/jh.v29i3.34844

Amalia, L., \& Saraswati, T. (2018). The Impact of Competencies Toward Teacher's Performance Moderated By the Certification in Indonesia. KnE Social Sciences. https://doi.org/10.18502/kss.v3i10.3363

Ammentorp, L., \& Madden, L. (2018). Learning from Others: Developing Preservice Teachers' Workplace Skills. The Educational Forum, 82, 85-96. https://doi.org/10.1080/00131725.2018.1385274

Arifin, H. M. (2014). The Influence of Competence, Motivation, and Organisational Culture to High School Teacher Job Satisfaction and Performance. International Education Studies, 8(1), p38. https://doi.org/10.5539/ies.v8n1p38

Bautista, A., \& Ortega-Ruiz, R. (2015). Teacher Professional Development: International Perspectives and Approaches. Psychology, Society \& Education, 7, 343-355. https://doi.org/10.25115/psye.v7i3.1020

Boudersa, N. (2011). The Importance of Teachers' Training Programs and Professional Development in the Algerian Educational Context: Toward Informed and Effective Teaching Practices.

Dahnial, I., Setiawan, D., \& Daulat, S. (2017). The Weakness of Civic Education Teacher's Competency in Curriculum at Senior High School, Stabat, Medan, Indonesia. British Journal of Education, 5(10), 51-61.

Hanushek, E. A., Piopiunik, M., \& Wiederhold, S. (2019). The Value of Smarter Teachers: International Evidence on Teacher Cognitive Skills and Student Performance. Journal of Human Resources, 54(4), 857-899. https://doi.org/10.3368/jhr.54.4.0317.8619R1

Hine, G. S. C. (2013). The Importance of Action Research in Teacher Education Programs. Educational Research, 23(2).

Indrawati, C. D. S., \& Octoria, D. (2016). Continuous Professional Development to Improve the Teachers' Competencies. Proceeding of the International Conference on Teacher Training and Education, 2(1), 656-663.

Johnson, A. P. (2012). A Short Guide to Action Research (4th ed.). New Jersey: Pearson Education

Kennedy, M. M. (2016). How Does Professional Development Improve Teaching? Review of Educational Research, 86(4), 945-980. https://doi.org/10.3102/0034654315626800

Kunlasomboon, N., Wongwanich, S., \& Suwanmonkha, S. (2015). Research and Development of Classroom Action Research Process to Enhance School Learning-ScienceDirect.

https://www.sciencedirect.com/science/article/pii/S1877042815002785

Marinković, S., Bjekić, D., \& Zlatić, L. (2012). Teachers' Competence as the Indicator of the Quality and Condition of Education. Project Paper Report.

Mustafa, M. N. (2013). Professional Competency Differences among High School Teachers in Indonesia. International Education Studies, 6(9), p83. https://doi.org/10.5539/ies.v6n9p83

Nhu, N. T., Loi, N. T. N., \& Thao, N. T. P. (2016). Factors Affecting Secondary and High School Teachers' Professional Competence in Ethnic Minority Areas - A Case of Tay Nguyen, Vietnam. International Journal of Education and Research, 4(11), 151-164.

Novozhenina, A., \& Pinzón, M. (2018). Impact of a Professional Development Program on EFL Teachers' Performance. HOW, 25, 113-128. https://doi.org/10.19183/how.25.2.406

Osamwonyi, E. F. (2016). In-Service Education of Teachers: Overview, Problems and the Way Forward. Journal of Education and Practice, 7(26), 83-87.

O'Shea, M. (2019). The Role of Teacher Emotional Intelligence in Determining Relationship Quality with Students. 202.

Paige, R. (2002). Meeting the Highly Qualified Teachers Challenge: The Secretary's Annual Report on Teacher Quality. US Department of Education. https://eric.ed.gov/?id=ED513876

Panggabean, M. S., \& Himawan, K. K. (2016). The Development of Indonesian Teacher Competence Questionnaire. Journal of Educational, Health and Community Psychology, 5(2), 1. https://doi.org/10.12928/jehcp.v5i2.5134

Rahman, D. F. (2011). Relationship between Training of Teachers and Effectiveness Teaching. International Journal of Business and Social Science, 2(4), 150-160.

Richards, J. C. (2017). Teaching English through English: Proficiency, Pedagogy and Performance. RELC Journal, 48(1), 7-30. https://doi.org/10.1177/0033688217690059

Selvi, A. F. (2016). The Role of Teacher Education at a Crossroads of Tensions and Opportunities. Asian Englishes, 18(3), 258264. https://doi.org/10.1080/13488678.2016.1237010 
Selvi, K. (2010). Teachers' Competencies. Cultura International Journal of Philosophy of Culture and Axiology, 7(1), 167-175. https://doi.org/10.5840/cultura20107133

Suyidno, S., \& Yamin, M. (2015). Analisis Kelemahan Uji Kompetensi Guru (UKG) SMPN di Kota Banjarmasin (Bahasa Inggris). Jurnal Kebijakan Pembangunan.

Tanang, H., \& Abu, B. (2014). Teacher Professionalism and Professional Development Practices in South Sulawesi, Indonesia. Journal of Curriculum and Teaching, 3(2), 25-42. https://doi.org/10.5430/jct.v3n2p25

Taniredja, T., \& Abduh, M. (2016). Pedagogical, Personality, Social and Professional Competence in Correlation with Teachers' Performance (Correlational Study of Junior High School Teacher at SMPN 3 Purwokerto). The $2^{\text {nd }}$ International Conference on Science, Technology, and Humanity.

Undang-Undang Republik Indonesia Nomor 14 Tahun 2005 Tentang Guru dan Dosen

Undang-Undang Republik Indonesia Nomor 20 Tahun 2003 Tentang Sistem Pendidikan Nasional.

Weda, S. (2016). Students' Voice Toward Good English Teachers' Characteristics at Secondary Schools in Indonesia. ELT WORLDWIDE, 3(1), 78-90. https://doi.org/10.26858/eltww.v3i1.1882

Wulyani, A. N. (2017). Professional Development of English Language Teachers in Malang, Indonesia: Institutional and Individual Perspectives. 